\title{
Process Based Approach towards Students' Creativity in Writing English Paragraph
}

\author{
Siti Syafi'atul Qomariyah \\ IKIP Mataram, Indonesia \\ e-mail:viamboice@gmail.com \\ Dira Permana \\ IKIP Mataram, Indonesia \\ e-mail: dira87permana@gmail.com
}

\begin{abstract}
:
The research entitled "Process based Approach towards Students' English Paragraph Writing Ability" aims to discover whether or not Process based Approach is effective or not towards students' English paragraph writing ability. This was a queasy-experimental research with pretest-posttest control group design. The population of the study was the fourth semester students of Writing subject of English Department at Language and Art Education Faculty of IKIP Mataram in the academic year of 2016/2017. Samples of the study were IV-E and IV-F taken through cluster random sampling technique. To determine the experimental and control class, lottery was used. Instrument of the research was paragraph writing test. Techniques of analyzing data were descriptive and inferential statistic analysis. Data of samples were in normal distribution since the value of sig (081) was higher than the value of alpha (0.05). Data of samples were also homogeneous as the value of sig (012) was higher than the value of alpha (0.05). Based on the result of ttest of two-tailed independent samples, it was found that the value of sig (196) was lower than the value of alpha at the level of significance (0.05). It means that Process based Approach was not effective towards students' English paragraph writing ability.
\end{abstract}

Keywords: process based approach, paragraph writing ability 


\section{Introduction}

Writing skill has a special spectrum in the process of language learning. To have the ability to write makes language learners easily share any ideas in the written form that any readers further read and grasp those ideas conveyed. Writing, thus, is not just about ideas to write but also the way they compose the elements of writing well (Setyowati, 2016). Having the ability to write by language learners is not only used to be a tool to bring for written messages to public but also to develop learners' insight of any other disciplines as a part of knowledge enrichment. It helps language learners convey point of views on certain topic leading to opening new paradigm on current issues. One of the realizations of the learner's ability to write in English is the ability to produce a good paragraph as an integral part of academic writing. Once learners have good paragraphs, longer composition will be might be well created. Ariyanti (2016) claims that to produce a good writing, every writer should explore ideas, pour down our thoughts on paper or on the computer, organize our writing, writing the first draft, revise the draft, and produce the final copy.

Yet, distinctive situation towards today's language learners in their process of learning a language in relation with writing ability has successfully created unusual worry on carelessness and disability to make good paragraph writing, although they are higher level students. The image that higher level students have more in-depth insight on various disciplines of learning, particularly language is apparently not in line with the fact that they are in a worrying condition. The disability of the students to make good paragraph writing can be seen from their writing products within the learning which are still far from being expected. Nurhayati (2016) and Qonitatun (2016) state that the writing problems faced by students including: lack ideas, organizing of ideas, rhetoric or pattern of thought, cohesion and coherence. Meanwhile, Martinez and Irwin (2016) claims that it is perhaps difficult for them to establish a relationship between the texts they have to write in the university environment and those they have thus far encountered in their daily lives or at school, and as a result, students have trouble contextualising their writing.

Based on an observation in the fourth semester students of English department at IKIP Mataram who programmed Writing subject, it was found that the disability of majority students to present correct topics for their paragraph which are often in complete sentences rather than phrases. The students' paragraph topic statements are not appropriately stated yet; they are mostly not in response to the topics proposed. The students' supporting sentences are not clearly elaborated to explain further about the topic statements. And, the concluding sentences are not precisely stated to end writing their paragraphs. Next to them, the use of punctuation which signed the order of the sentence was also inappropriate. However, these difficulties can be tolerated since it is a productive skill that is more complicated that it seems at first, and often seems to be the most difficult of the skills since it has a number of micro skills such as using orthography correctly, spelling, and punctuation (Orwig in Armana, 2011).

Ideally a good paragraph is that it considers a topic to be discussed. The paragraph topic directs discussion on what ideas which are going to be further explored in a 
paragraph. The topic of discussion is commonly stated in a phrase and not in a complete sentence. Next to them, a good paragraph is composed of three main components; topic sentence, supporting sentence, and the concluding sentence. Then the question is that how these difficulties can be minimized or even eliminated within writing learning process that students have better paragraph writing ability. This simple question can be optionally solved by applying Process based Approach as the approach to teach students in learning to write English paragraph. Process based Approach is a teaching of process triggering students to create their own ideas step-by-step to result in a comprehensive organization of paragraph.

Therefore, to provide for an appropriate approach in teaching writing will be able to lead students into having higher sense of creativity in learning to write English, particularly in learning to write English paragraph. Process based approach, based on the elaboration on the teaching approach, is claimed to be an effective teaching approach to pump up students' creativity in learning to write. Seeing the phenomena above, the researchers have in depth interest to research a process based approach to teaching writing entitled:"Process based Approach towards Students' Writing English Paragraph Ability". The use of process based approach is expected to be effective steps for students in the efforts of creatively developing their English paragraph writing ability. The main research question of the study is: Is Process based Approach effective towards students' English paragraph writing ability at the fourth semester students of English Department at IKIP Mataram in the academic year of 2016/2017?

\section{Literature Review}

\subsection{Paragraph}

Oshima (2006: 2) defines paragraph as a group of related sentences that discuss one (and usually only one) main idea. A paragraph can be as short as one sentence or as long as ten sentences. The number of sentences is unimportant, however, the paragraph should be long enough to develop the main idea clearly. Further, Irawati, (2013: 5) states that paragraph is the basic unit of composition. Paragraph usually consists of several sentences, they are topic sentence, supporting or developing sentence and concluding sentence. Thus, it can be concluded that paragraph is a unit of composition consisting of several related sentences; topic sentence, supporting sentence, and concluding sentence which are coherently composed and usually developing one main idea.

\subsection{Structures of Paragraph}

Rumney (2003) divides paragraph structures into three i.e., the topic sentence, supporting evidence/analysis, and concluding observation. The Topic Sentence serves two functions: first, it functions as the thesis of your paragraph; second, it pushes the thesis of your essay forward and presents an arguable point. The topic sentence is usually the first or second sentence of a paragraph. Occasionally, you may find it interesting or necessary to place the topic sentence at the end of the paragraph, but don't make a habit of it!. Supporting Evidence/Analysis makes your claim digestible. You need to find a balance between evidence you provide (facts, 
quotations, summary of events/plot, etc.) and analysis (interpretation of evidence).The Concluding Observation closes your paragraph with an observation that is more than just summary of the contents of the paragraph. The concluding observation provides a final idea that leads to the next step in your argument.

\subsection{Assessing Paragraph}

Brown (2003: 235) writes that assessment of paragraph development takes a number of different forms, i.e. (1) topic sentence which assess: specifying the writing of a topic sentence, scoring points for its presence or absence, and scoring and/or commenting on its effectiveness in stating the topic, (2) topic development within a paragraph which assesses: the clarity of expression of ideas, the logic of the sequence of and connections, the cohesiveness or unity of the paragraph, the overall effectiveness or impact of the paragraph as a whole, (3) development of main supporting ideas across paragraphs which assess: addressing the topic, main idea, or principal purposes, organizing and developing supporting ideas, using appropriate details to undergird supporting ideas, showing facility and fluency in the use of language and demonstrating syntactic variety.

\subsection{Process Based Approach}

Holmes (2004) in Elshirbini, et al. (2013) states that the use of a process-oriented approach to facilitate the planning and production stages of writing for adult students of English as a Foreign or Second Language and identifies some features of this approach and provides some suggestions to develop activities in order to humanize and make a more positive and effective experience from writing.Tompkins (1990) assured that this current emphasis in writing instruction focuses on the process of creating writing rather than the end product.

Graves, et al (2007) in Wati (2013: 19) writes the stages of writing process involving (1) pre-writing, (2) drafting, and writing, (3) sharing and responding, (4) revising ad editing, and (5) publishing. Pre-writing, Prewriting strategies such as brainstorming and freewriting (explained below) can help writers find ideas, collect information, activate tacit knowledge, and organise their thoughts. Drafting, In this stage, the students are encouraged to develop their ideas into rough drafts without considering the grammatical accuracy first. As previously descrbed in the process based writing. The grammatical accuracy will be emphasized during the revising stage (Widodo, 2008). Sharing and responding, Sharing means that sharing your work with other people and getting some feedback about how you are doing (Peha, 2002: 10). Meanwhile, responding or giving feedback is primarily intended to see students first or second drafts (Widodo, 2008). Revising and editing, Widodo (2008) states that revising does not simply involve looking at language errors but also addresses the global content and organization of ideas so that the writer's intent is made clearer. Publishing, To publish means preparing a piece of writing so that it can be read, understood, and enjoyed by the public (Peha, 2002: 19). Thus, this publishing stage requires students to publish their writing product as result of facing a longer process of learning. 
Brown (2001) in Onozawa (2010, p.157) states that the process approach is advantageous to students in language learning because students are the creators of language, they need to focus on content and message, and their own intrinsic motives are valued. Despite genres' beneficial roles in helping learners to produce written work with confidence, it underestimates the skills required to produce content, and the other concern is that it neglects learners' self-sufficiency (Byram, 2004, p. 236).

\section{Research Methodology}

This research applies a queasy-experimental research with pretest-posttest control group design. There are three variables of the research which are dependent, independent variable, and moderator variable. The independent variable constitutes the teaching approach which is in this case process based approach, while the dependent variable represents students' English paragraph writing ability.

Population of the research was the fourth semester students of English Department at IKIP Mataram in the academic year of 2016/2017 taking Writing subject, consisting of 6 classes. The overall total number of population were 174 students. The samples of the research were IV-E and IV-F with the entire total of students were 58 students. IV-F class was taken as the experimental group and IV-E was as the control group. The researchers applied cluster random sampling technique to take samples of the research. In determining the experimental and the control classes, lottery was used. Instrument of the research used was the writing test using persuasion paragraph which had been tested its readability.

\section{Findings}

This section provides the data of students' paragraph writing for experiemental group and data of students' paragraph writing for control group. the description are presented below.

\subsection{Data of Students' Paragraph Writing for Experiemental Group}

The data of students' paragraph writing for experiemental group includes the the result of pre-test and the result of post-test.

\subsubsection{The Result of Pre-Test}

Based on the result of computation, it was found that the result of the students' initial score of their paragraph writing ability before they were taught by using process based approach was still categorized low. This low score was proved by only few students who scored 70 as the highest score and which was categorized into good category. Most students scored under enough category and even poor category with 35 as the lowest score. based on the descriptive analysis, it was found that the mean score of the students' paragraph writing ability was 57.00, median was 60.00 , and the standard deviation was 11.323. Further, study the following frequency distribution and polygon and histogram. 
Table 1. Frequency Distribution of Pre-Test

\begin{tabular}{|c|c|c|c|c|c|}
\hline $\begin{array}{c}\text { Class } \\
\text { Limits }\end{array}$ & $\begin{array}{c}\text { Class } \\
\text { Boundaries }\end{array}$ & Midpoint & Tally & F & $\%$ \\
\hline $30-36$ & $29.5-36.5$ & 33 & II & 2 & 6.897 \\
\hline $37-43$ & $36.5-43.5$ & 40 & II & 2 & 6.897 \\
\hline $44-50$ & $43.5-50.5$ & 47 & HII & 4 & 13.793 \\
\hline $51-57$ & $50.5-57.5$ & 54 & HII & 5 & 17.241 \\
\hline $58-64$ & $57.5-64.5$ & 61 & HII II & 7 & 24.138 \\
\hline $65-71$ & $4.5-71.5$ & 68 & IHI IIII & 9 & 31.034 \\
\hline Total & & & & 29 & $100 \%$ \\
\hline
\end{tabular}

Graphic 1. Histogram and Polygon of Experimental Group Pre-Test

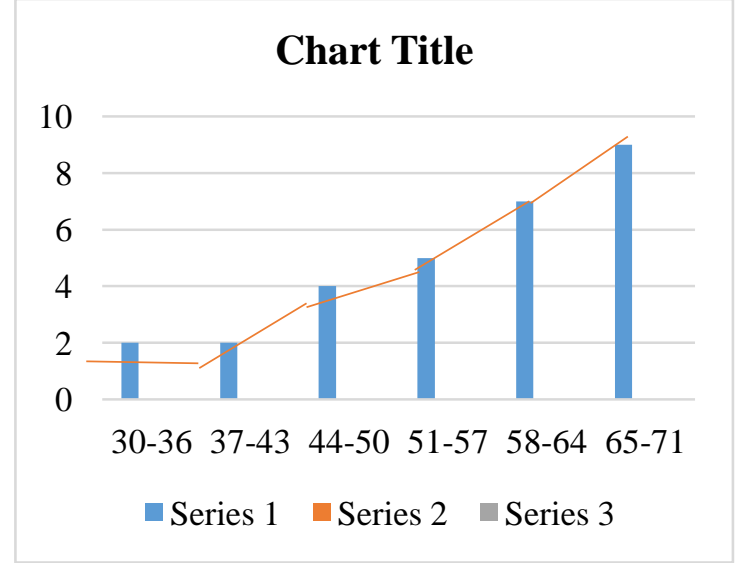

\subsubsection{The Result of Post-Test}

As the students were taught by using process based approach the students of experimental group tent to have better score in which the highest score of the students' paragraph writing was 82 and the lowest score was 62 . Thus, there was found improvement of score about 12 point compared to the previous score in pre test from 70 to 82 . If it is seen from the result of the descriptive analysis, the mean score was 70.31, median was 71.00, and the standard deviation was 7.137. Further, study the following frequency distribution and polygon and histogram.

Table 2. Frequency Distribution of Post-Test

\begin{tabular}{|c|c|c|c|c|c|}
\hline $\begin{array}{c}\text { Class } \\
\text { Limits }\end{array}$ & $\begin{array}{c}\text { Class } \\
\text { Boundaries }\end{array}$ & Midpoint & Tally & F & $\%$ \\
\hline $60-63$ & $59.5-63.5$ & 61.5 & IH IIII & 9 & 31.034483 \\
\hline $64-67$ & $63.5-67.5$ & 65.5 & II & 2 & 6.896552 \\
\hline $68-71$ & $67.5-71.5$ & 69.5 & IIII & 4 & 13.793103 \\
\hline $72-75$ & $71.5-75.5$ & 73.5 & IIII & 4 & 13.793103 \\
\hline $76-78$ & $75.5-78.5$ & 77.5 & HII II & 7 & 24.137931 \\
\hline $80-83$ & $78.5-83.5$ & 81.5 & III & 3 & 10.344828 \\
\hline Total & & & & 29 & $100 \%$ \\
\hline
\end{tabular}


Graphic 2. Histogram and Polygon of Experimental Group Post-Pest

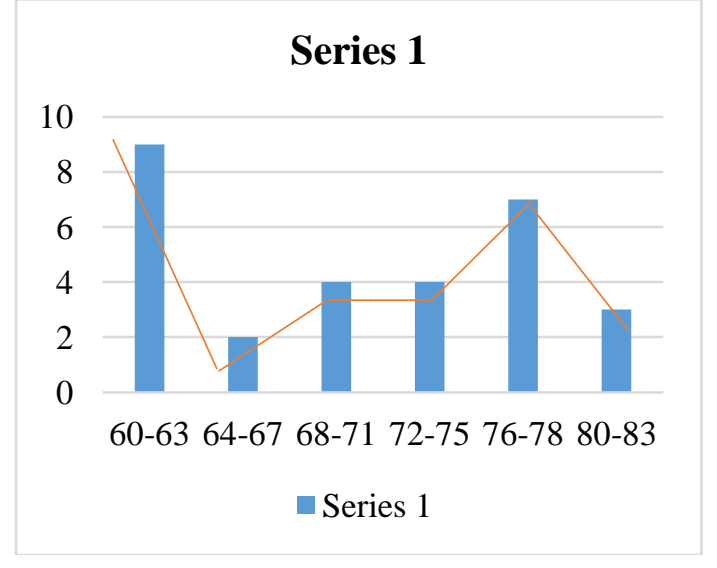

\subsection{Data of Students' Paragraph Writing for Control Group}

\subsubsection{The Result of Pre-Test}

Based on the result of computation, it was found that the result of the students' initial score of their paragraph writing ability before they were taught by using process based approach was mostly still categorized low. This was proved by only two students who scored 70 as the highest score and which was categorized into good category. However, most students scored under fair category and even poor category with 35 as the lowest score. Based on the descriptive analysis, it was found that the mean score of the students' paragraph writing ability was 58.03, median was 60.00 , and the standard deviation was 9.124. Further, study the following frequency distribution and polygon and histogram.

Table 3. Frequency Distribution of Control Group Pre-Test

\begin{tabular}{|c|c|c|c|c|c|}
\hline $\begin{array}{c}\text { Class } \\
\text { Limits }\end{array}$ & $\begin{array}{c}\text { Class } \\
\text { Boundaries }\end{array}$ & Midpoint & Tally & F & $\%$ \\
\hline $35-40$ & $34.5-40.5$ & 37.5 & III & 3 & 10.344 \\
\hline $42-46$ & $40.5-46.5$ & 43.5 & I & 1 & 6.897 \\
\hline $47-52$ & $46.5-52.5$ & 49.5 & I & 1 & 13.793 \\
\hline $53-58$ & $52.5-58.5$ & 55.5 & $\begin{array}{c}\text { IHI } \\
\text { IIII }\end{array}$ & 9 & 17.241 \\
\hline $59-64$ & $58.5-64.5$ & 61.5 & $\begin{array}{c}\text { IHI } \\
\text { II }\end{array}$ & 7 & 24.138 \\
\hline $65-70$ & $64.5-70.5$ & 67.5 & $\begin{array}{c}\text { IHI } \\
\text { III }\end{array}$ & 8 & 27.587 \\
\hline Total & & & & 29 & $100 \%$ \\
\hline
\end{tabular}


Graphic 3. Histogram and Polygon of Control Group Pre-Test

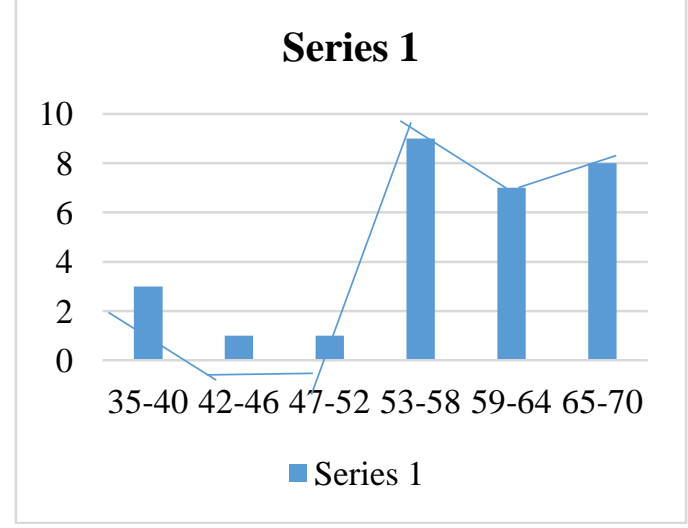

\section{.4.2.2 The Result of Post-Test}

As the students were taught by using process based approach the students of control group also had better score the same as that of in the experimental group in which the highest score of the students' paragraph writing was 80 and the lowest score was 60. Thus, there was also found improvement of score for about 10 points from 70 to 80. If it is seen from the result of the descriptive analysis, the mean score of the students' paragraph writing ability was 69.14 , median was 68.00 , and the standard deviation was 5.249. However, the mean score of experimental group was higher than that of the control group. Further, study the following frequency distribution and polygon and histogram.

Table 4. Frequency Distribution of Control Group Post-Test

\begin{tabular}{|c|c|c|c|c|c|}
\hline $\begin{array}{c}\text { Class } \\
\text { Limits }\end{array}$ & $\begin{array}{c}\text { Class } \\
\text { Boundaries }\end{array}$ & Midpoint & Tally & F & $\%$ \\
\hline $60-63$ & $59.5-63.5$ & 61.5 & $\begin{array}{c}\text { IHI } \\
\text { IIII }\end{array}$ & 4 & 13.793103 \\
\hline $64-67$ & $63.5-67.5$ & 65.5 & II & 9 & 31.03448 \\
\hline $68-71$ & $67.5-71.5$ & 69.5 & IIII & 6 & 20.6897 \\
\hline $72-75$ & $71.5-75.5$ & 73.5 & IIII & 6 & 20.6897 \\
\hline $76-78$ & $75.5-78.5$ & 77.5 & IHI & 3 & 10.3449 \\
& & & II & & \\
\hline $80-83$ & $78.5-83.5$ & 81.5 & III & 1 & 3.449 \\
\hline Total & & & & 29 & $100 \%$ \\
\hline
\end{tabular}




\section{Graphic 4. Histogram and Polygon of Control Group Post-Test}

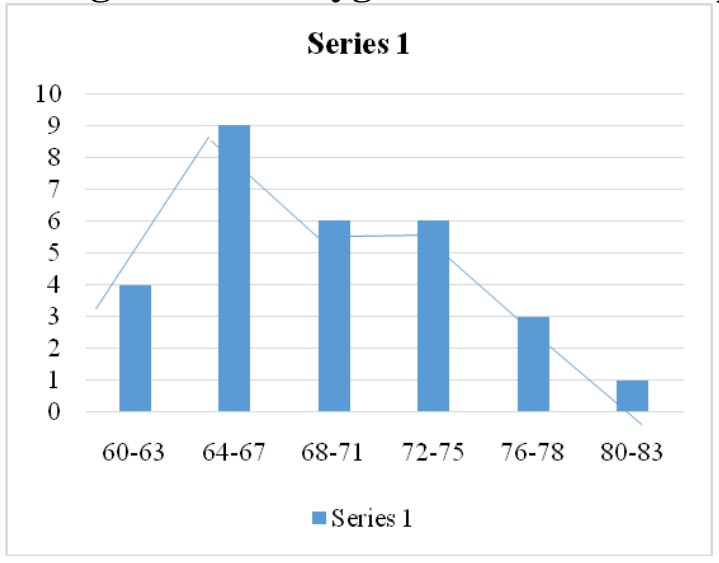

\section{Discussion}

Based on the result of research finding and computation, it was found that the result of the students' initial score of their paragraph writing ability before they were taught by using process based approach of both experimental and control groups was still categorized low. These low categories were proved by most students scoring under expected scores. In the experimental group, for instance, only few students who scored 70 as the highest score and which was categorized into good category. Most other students scored under fair category. And, even the students scored poor category with 35 as the lowest score. Furthermore, the mean score of the students' paragraph writing ability was 57.00 . Meanwhile, in the control group, it was found that the result of the students' initial score of their paragraph writing ability before they were taught by using process based approach was almost the same as that of in the experimental group in which it was also still categorized low. This was proved by only two students who scored 70 as the highest score and which was categorized into good category. However, most students scored under fair category and even poor category with 35 as the lowest score. In the term of the mean score, the students' paragraph writing ability was 58.03. The mean scores of both groups were slighlty different, meaning that the students came from the same ability of writing.

However, after the students were taught by using process based approach the students of both groups, either experimental and control groups changed to have better scores. It was found that the highest score of the students' paragraph writing in the experimental group was 82 and the lowest score was 62. There was found improvement of score about 12 points from the previous score in pre test which was 70. Even, the mean score of the students' paragraph writing ability changed to 70.31. Meanwhile, the students of control group also had better score the same as that of in the experimental group in which the highest score of the students' paragraph writing was 80 and the lowest score was 60 . There was also found improvement of score for about 10 points from 70 . And, the mean score of the students' paragraph writing ability was 69.14. 
The change of score both in pre-test and post-test could be interpreted that the use of process based approach had given positive effect towards students' ability in writing English paragraph. This positive effect was in line with what Holmes in Elshirbini, et al. (2013) previously states that process-oriented approach is to facilitate the planning and production stages of writing for adult students of English as a Foreign or Second Language and identifies some features of this approach and provides some suggestions to develop activities in order to humanize and make a more positive and effective experience from writing.

Unfortunately, although the use of process based approach had successfully given positive result towards students' ability of writing English paragraph, it did not mean that the use of process based approach was effective towards students' creativity in writing English paragraph. The English teachers need find a way to encourage the students' creativity because in learning English as a second language, creativity, as one of these human factors, is believed to significantly affect L2 learning and life skills among human beings (Zaker, 2016). This was proved by the result of the t-test of independent sample in which the value of sig (196) was lower than the value of alpha (0.05) meaning that Ha was rejected and Ho was accepted.

\section{Conclusion}

Process based Approach gives positive effect towards students' students' English paragraph writing ability, in which the mean scores of students' paragraph writing ability in pre-test for experimental group is 57.00, while the control group is 58.03. Meanwhile, the mean scores of students' paragraph writing ability in post-test for experimental group is 70.31, while the control group is 69.14 . These results indicate that generaly process based approach has contributed positive effect towards students' ability of writing English paragraph in which both groups achieved better scores in their paragraph writing ability from pre-test to post-test. The mean score of the experimental group is higher than that of control group. However, the result of ttest of independent samples of two-tailed shows that process based approach is not effective towards students' ability of writing English paragraph due to the value of sig (196) is lower than the value of alpha (0.05). Thus, it can be concluded that process based approach is not effective towards students' English paragraph writing ability.

From the result of the study above, it can be suggested that finding an appropriate teaching approach in teaching students to write is neccessiated. The use of an appropriate teaching approach might lead to ability of the students to produce briliant ideas to develop in a composition, particularly a paragraph. on the other words, Process based Approach can be alternatively used by teachers and lectures to teach students writing their ideas in their process of learning to write English paragraphs in the classrooms although not each teaching approach lectures initiate to use in teaching can significantly give significant effect towards students' skill achievements. 
Qomariyah \& Permana, Process Based Approach towards Students' Creativity in Writing

\section{References}

Ariyanti, A. (2016). Shaping Students' Writing Skills: The Study of Fundamental Aspects in Mastering Academic Writing. Indonesian Journal of EFL and Linguistics, 1(1), 2016

Armana, Abu. R.A.M.(2011).The Impact of Remedial Program on English Writing Skills of the Seventh Grade Low Achievers at UNRWA Schools in Rafah. An Students' ESL Essay Writing. An Unpublished Thesis

Brown, D. (2003). Language Assessment: Principle and Classroom Practice. London: Longman

Byram, M. (2004). Genre and Genre-Based Teaching. The Routledge Encyclopedia of Language Teaching and Learning (pp. 234- 237). London: Routledge.

Elshirbini, et al. (2013). The Effect of the Genre-Based Approach to Teaching Writing on theEFL Al-Azhr Secondary Students' Writing Skills and Their AttitudesTowards Writin. Mansoura University

Irawati, T. (2013). Being An Excellent Writer With An Excellent Writing: Your Guide To Write in English As a Foreign Language. Madani: Malang

Martinez Lirola, Maria and Irwin, Derek S. (2016). Challenges in the Application of Genre Theory to Improve L2 Academic Writing: Effective Reports and Assessment. ASIAN TEFL, 1(1), 2016. DOI: http://dx.doi.org/10.21462/asiantefl.v1i1.4

Nurhayati , Dwi Astuti Wahyu. (2016). Using Local Drama in Writing and Speaking: EFL Learners' Creative Expression. Journal of English Language Teaching and Linguistics, 1(1), 2016. http://dx.doi.org/10.21462/jeltl.v1i1.13

Onozawa, Chieko. (2010). A Study of the Writing Process Approach: A Suggestion for an Electric Writing Approach. Research note, N0.10

Oshima. A. \& Hogue, Ann. (2006). Writing Academic English, Fourth Edition. New York: Pearson Education, Inc.

Peha, Steve. (2002). The Writing Process Notebook. Retrieve from http://www.ttms.org

Qonitatun, Q. (2016). The Quality of Essay Writing of Indonesian EFL Learners. ASIAN TEFL, 1(1), 55-76. DOI: http://dx.doi.org/10.21462/asiantefl.v1i1.6

Rumney, L. (2003). Paragraph structure. Nessbitt-Johnston Writing Center Hamilton College Clinton, New York 13323. All rights reserved

Setyowati, Lestari. (2016). Analyzing the Students' ability in Writing Opinion Essay Using Flash Fiction. Journal of English Language Teaching and Linguistics, 1(1), 2016. http://dx.doi.org/10.21462/jeltl.v1i1.1

Tompkins, G. (1997). Teaching and writing: Balancingprocess and product. Columbus, $\mathrm{OH}$ : Merrill Publishing Co.

Wati, NingSetio. (2013). The Effectiveness of Collaborative Writing Method to teach Writing Viewed from Students' Creativity. Thesis. UNS: Surakarta

Widodo, H.P. (2008). Process-Based Academic Essay Writing Instruction in an EFL Content. TESL Journal. 36 (1), 1

Zaker, Alireza. (2016). Literature and Creativity in an ELT Context. ASIAN TEFL, $1(2), 2016$ 